\title{
Batuk Kronik pada Anak: masalah dan tata laksana
}

\author{
Darmawan B Setyanto
}

Batuk kronik pada anak cukup banyak dijumpai dalam praktek sehari-hari. Pada pasien anak, gejala batuk yang kronik atau berulang dapat mengganggu aktivitas sehari-hari, mengurangi nafsu makan, dan pada akhirnya dapat mengganggu proses tumbuh kembang. Orang tua juga akan terganggu terutama bila gejala batuk lebih sering dan lebih berat pada malam hari. Batasan batuk kronik bermacam-macam, ada yang mengambil batas 2 minggu atau 3 minggu. Ada pula yang membagi batuk menjadi batuk akut, subakut, dan kronik. Antara batuk kronik dan batuk berulang seringkali sulit dibedakan. Ikatan Dokter Anak Indonesia (IDAI) menganut batasan tersendiri yaitu batuk kronik berulang (b.k.b) yang mencakup pengertian batuk kronik di dalamnya. Dua fungsi utama batuk, pertama sebagai mekanisme pertahanan respiratorik; kedua sebagai gejala yang mengindikasikan adanya gangguan / kelainan / penyakit di sistem respiratorik umumnya, dan sebagian di luar sistem respiratorik. Batuk akan timbul bila reseptor batuk terangsang. Pada anak, berbagai hal, keadaan, atau penyakit dapat bermanifestasi sebagai batuk. Sebagian besar etiologi berasal dari sistem respiratorik, sebagian kecil karena kelainan di sistem non-respiratorik. Untuk mendeteksi etiologi batuk, pemahaman tentang mekanisme batuktermasuk lokasi reseptor batuk sangat penting diketahui. Dengan pemahaman itu, kita akan tetap ingat bahwa batuk kronik juga dapat disebabkan oleh kelainan atau penyakit di luar sistem respiratorik. Pasien anak dengan batuk kronik dibagi menjadi dua kelompok, tanpa kelainan dasar yang nyata serta anak relatif tampak sehat, dan pasien dengan kelainan respiratorik yang nyata. Perlu pula diketahui etiologi yang sering timbul pada berbagai kelompok umur anak. Langkah diagnostik dimulai dari penggalian anamnesis yang mendalam, pemeriksaan fisis, dan pemeriksaan penunjang yang relevan. Tata laksana batuk kronik pada anak ditujukan kepada penyakit dasarnya, peran antitusif sangat terbatas.

Kata kunci: batuk kronik, mucociliary clearance

B atuk adalah pengeluaran sejumlah volume udara secara mendadak dari rongga toraks melalui epiglotis dan mulut. Melalui mekanisme tersebut dihasilkan aliran udara yang sangat cepat yang dapat melontarkan keluar material yang ada di sepanjang saluran respiratorik, terutama

Alamat Korespondensi:

Dr. Darmawan B Setyanto Sp.A(K)

Divisi Respirologi Departemen Ilmu Kesehatan Anak FKUI-RSCM Jl. Salemba no. 6, Jakarta 10430.

Telepon: 021-3100669. Fax.021-390 7743 saluran yang besar. Dengan demikian batuk mempunyai fungsi penting sebagai salah satu mekanisme utama pertahanan respiratorik. Mekanisme lain yang bekerja sama dengan batuk adalah bersihan mukosilier (mucociliary clearance). Batuk akan mencegah aspirasi makanan padat atau cair dan berbagai benda asing lain dari luar. Batuk juga akan membawa keluar sekresi berlebihan yang diproduksi di dalam saluran respiratorik, terutama pada saat terjadi radang oleh berbagai sebab. ${ }^{1,2}$

Selain sebagai mekanisme pertahanan respiratorik, batuk juga dapat berfungsi sebagai 'alarm' yang 
memberitahu adanya gangguan pada sistem respiratorik atau sistem organ lainnya yang terkait. Hampir semua keadaan yang mengganggu sistem respiratorik dan beberapa gangguan ekstra-respiratorik, memberikan

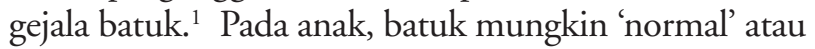
merupakan gejala penyakit respiratorik dan jarang merupakan gejala penyakit non-respiratorik. ${ }^{3}$

Batuk merupakan salah satu keluhan klinis yang paling banyak membawa pasien mencari pertolongan medis. ${ }^{1,4,5}$ Gangguan yang paling sering adalah kelelahan, insomnia, suara serak, nyeri otot dan tulang, berkeringat, dan inkontinensia urin. Tekanan udara tinggi intratorakal yang kemudian dilepaskan mendadak dapat menyebabkan berbagai komplikasi hampir di semua sistem organ. ${ }^{5}$ Pada anak, gejala batuk terutama yang kronik atau berulang dapat berakibat mengganggu aktivitas sehari-hari termasuk kegiatan belajar, mengurangi nafsu makan, dan pada akhirnya dapat mengganggu proses tumbuh kembang. Orang tua juga akan terganggu terutama bila gejala batuk lebih sering dan lebih berat pada malam hari.

Batuk tidak selalu berarti patologis atau abnormal. Seperti telah dikemukakan di atas, sebagai mekanisme pertahanan respiratorik, batuk diperlukan untuk membersihkan jalan napas dari mukus sekresi respiratorik, pada orang dewasa mencapai $30 \mathrm{ml} /$ hari. ${ }^{1}$ Sebuah studi yang mengukur batuk secara obyektif menemukan bahwa anak sehat dengan rerata umur 10 tahun biasanya mengalami $10 x$ batuk (rentang hingga 34) dalam 24 jam, sebagian besar batuk terjadi pada siang hari. ${ }^{6}$ Angka ini meningkat selama infeksi respiratorik, yang bisa terjadi hingga 8x lipat per tahun pada anak sehat. Walaupun sebagian besar anak batuk tidak mengalami kelainan paru yang serius, batuk dapat sangat mengganggu dan sulit untuk diatasi. Sampai batas tertentu batuk kronik pada anak adalah normal dan mempunyai prognosis yang baik. Jika batuk kronik yang terjadi sangat sering atau berat, maka sangat mungkin terdapat penyakit yang mendasarinya. ${ }^{4}$

\section{Batasan}

Mengenai batasan batuk akut dan kronik terdapat beberapa pendapat. Beberapa penulis mengajukan batas batuk 3 minggu atau lebih sebagai batas batuk kronik. ${ }^{4,7,5}$ Penulis lain membagi menjadi 3 kelompok, batuk akut, sub-akut, dan kronik. ${ }^{3,8}$ Kurang dari 2 minggu termasuk batuk akut, antara 2-4 minggu disebut batuk sub-akut, sedangkan lebih dari 4 minggu disebut batuk kronik. ${ }^{3}$ Terdapat penulis lain mengusulkan batas akut adalah kurang dari 3 minggu, subakut antara 3-8 minggu, dan kronik 8 minggu atau lebih. ${ }^{8}$ Istilah lain yang berdekatan dengan batuk kronik, yaitu batuk berulang (recurrent cough). Secara teoritis etiologi batuk kronik berbeda dengan etiologi batuk berulang, sehingga seharusnya dibedakan secara tegas antara kedua hal tersebut. Namun dalam praktek sehari-hari seringkali sangat sulit membedakan kedua hal tersebut. ${ }^{9}$ Penyebab batuk tersering pada anak yang dihadapi dalam praktek sehari-hari adalah infeksi respiratorik akut (IRA) yang sebagian besar penyebabnya virus. ${ }^{3}$ Sebagian IRA karena virus tertentu dapat menyebabkan batuk yang berkepanjangan yang disebut post infectious cough. Bila seorang anak mengalami keadaan ini berulang-ulang akan terlihat sebagai batuk kronik.

Terdapat kesulitan dalam membedakan kedua hal tersebut, maka dalam bidang Ilmu Kesehatan Anak dikenal istilah batuk kronik berulang (BKB) atau chronic recurrent cough. Sebenarnya istilah itu terdiri dari dua pengertian dengan kata penghubung dan/ atau, yaitu tepatnya batuk kronik dan atau batuk berulang. Pengertiannya bila terpenuhi salah satu saja maka sudah bisa dimasukkan sebagai BKB. Pada diskusi Kelompok Pulmonologi Anak dalam Kongres Nasional Ilmu Kesehatan Anak (KONIKA) V tahun 1981 di Medan telah disepakati bahwa BKB adalah keadaan klinis oleh berbagai penyebab dengan gejala batuk yang berlangsung selama 2 minggu atau lebih dan/atau batuk yang berulang sedikitnya 3 episode dalam 3 bulan berturut, dengan atau tanpa disertai gejala respiratorik atau non-respiratorik lainnya. ${ }^{?}$

\section{Mekanisme batuk}

Batuk merupakan suatu refleks kompleks yang melibatkan banyak sistem organ. Batuk akan terbangkitkan apabila ada rangsangan pada reseptor batuk yang melalui saraf aferen akan meneruskan impuls ke pusat batuk tersebar difus di medula. Dari pusat batuk melalui saraf eferen impuls diteruskan ke efektor batuk yaitu berbagai otot respiratorik. ${ }^{2,5}$ Bila rangsangan pada reseptor batuk ini berlangsung berulang maka akan timbul batuk berulang, sedangkan bila rangsangannya terus menerus akan menyebabkan batuk kronik. 
Anatomi refleks batuk telah diketahui secara rinci. Reseptor batuk terletak dalam epitel respiratorik, tersebar di seluruh saluran respiratorik, dan sebagian kecil berada di luar saluran respiratorik misalnya di gaster. Lokasi utama reseptor batuk dijumpai pada faring, laring, trakea, karina, dan bronkus mayor. Lokasi reseptor lainnya adalah bronkus cabang, liang telinga tengah, pleura, dan gaster. ${ }^{1,7}$ Ujung saraf aferen batuk tidak ditemukan di bronkiolus respiratorik ke arah distal. Berarti parenkim paru tidak mempunyai resptor batuk. ${ }^{5}$ Reseptor ini dapat terangsang secara mekanis (sekret, tekanan), kimiawi (gas yang
Pada anak berbagai hal, keadaan, atau penyakit dapat bermanifestasi sebagai batuk. Sebagian besar etiologi berasal dari sistem respiratorik, namun tidak boleh dilupakan kelainan atau penyakit dari sistem lain yang memberikan gejala batuk. Untuk mendeteksi etiologi batuk, pemahaman tentang mekanisme batuk, termasuk lokasi reseptor batuk sangat penting diketahui. ingat bahwa batuk kronik juga dapat disebabkan oleh kelainan atau penyakit di luar sistem respiratorik.

Secara garis besar, batuk kronik pada anak dapat dibagi menjadi 2 kelompok $^{4}$ (Tabel 1)

Tabel 1. Diagnosis banding batuk kronik pada anak ${ }^{4}$

\begin{tabular}{ll}
\hline Kelompok I & Kelompok II \\
Anak relatif tampak sehat & Penyakit dasar nyata \\
\hline - Bronkitis akut viral berulang & Penyakit paru supuratif kronik \\
- Batuk pasca infeksi & - Aspirasi paru berulang \\
- Pertussis and tussis like cough & - Benda asing \\
- Asma & - Bronkiektasis \\
- Reftnasal drip & - Defisiensi imun \\
- Psikogen & \\
& - Lesinesia silia primer \\
& - Trakeobrontorik \\
& - Tumorkulosis (kompresia kolaps lobus, kista, sekuestrasi \\
\hline
\end{tabular}

merangsang), atau secara termal (udara dingin). Mereka juga bisa terangsang oleh mediator lokal seperti histamin, prostaglandin, leukotrien dan lain-lain, juga oleh bronkokonstriksi.?

\section{Etiologi}

Batuk kronik seringkali secara simultan disebabkan oleh lebih dari satu etiologi. Pada pasien dewasa yang tidak terpajan asap rokok serta gambaran foto toraks tanpa kelainan khusus, penyebab tersering batuk kronik adalah sindrom PND (postnasal drip), asma, dan RGE (refluks gastro-esofagus). Postnasal drip merupakan penyebab tersering batuk kronik, baik sebagai penyebab tunggal atau kombinasi. Pada anak, penyebab tersering batuk kronik adalah asma, IRA (infeksi respiratorik akut) berulang baik atas atau bawah, serta RGE. Penyebab yang lebih jarang adalah anomali kongenital, aspirasi kronik berulang, atau pajanan dengan polutan lingkungan termasuk asap rokok. ${ }^{5}$
- Batuk kronik non spesifik semata (isolated) tanpa wheezing pada anak yang relatif tampak sehat

- Batuk kronik karena terdapat kelainan respiratorik yang serius.

\section{Pendekatan diagnostik}

Menurut American College of Chest Physicians dalam consensus panel report tahun 1998, pendekatan diagnostik dalam tata laksana batuk kronik pada anak adalah serupa dengan pendekatan pada pasien dewasa. ${ }^{5}$ Bila menghadapi pasien dengan batuk kronik, pendekatan diagnostik dengan pemahaman mekanisme dan anatomi refleks batuk sangat membantu. Penerapan cara tersebut dapat mengidentifikasi sekitar 90\% kasus, dengan keberhasilan terapi yang lebih kurang sama tingginya. ${ }^{8}$

Pada umumnya dokter anak kurang setuju pendekatan diagnostik maupun tata laksana penyakit disamakan antara anak dengan dewasa. Anak 
bukanlah orang dewasa dalam ukuran kecil. Perbedaan ini meliputi banyak sekali aspek. Perbedaan yang paling hakiki adalah karena ada proses tumbuh kembang yang sedang berlangsung pada masa kanak. Selain itu pola penyakit respiratorik pada anak berbeda nyata dengan orang dewasa. ${ }^{3}$ Penyakit yang sama bisa memberi gejala yang berbeda antara anak dengan dewasa. Sebaliknya gejala yang sama bisa mengarah ke penyakit yang berbeda. Bukti terkini menunjukkan bahwa adalah keliru melakukan ekstrapolasi 3 penyebab utama batuk kronik pada orang dewasa (asma, rinitis-sinusitis, dan RGE) untuk pasien anak. ${ }^{10,11}$ Oleh karena itu, etiologi dan manajemen batuk pada anak harus pula jelas dibedakan dengan orang dewasa. ${ }^{3}$

Pada anak dapat dijumpai berbagai kelainan kongenital ataupun gangguan fungsi organ sebagai penyebab batuk kronik yang tidak ditemukan pada orang dewasa. Salah satu cara yang berguna adalah dengan memilah anak dalam kelompok usia, seperti masa bayi, balita, atau anak yang lebih besar dan remaja. ${ }^{7}$ Tabel 2 menunjukkan kemungkinan penyebab batuk kronik sesuai kelompok umur.

Untuk membantu pendekatan diagnostik, beberapa hal yang bisa digunakan sebagai petunjuk. Kelainan respiratorik khusus yang mendasari timbulnya batuk, tertera pada Tabel $3 .^{3}$

Bila ditemukan satu atau lebih petunjuk di atas, kemungkinan besar anak masuk dalam kelompok II, yaitu batuk kronik yang disebabkan kelainan respiratorik yang nyata.

\section{Anamnesis}

Langkah awal penilaian anak dengan batuk kronik adalah menentukan karakteristik batuk. Perlu

Tabel 3. Petunjuk penyakit respiratorik khusus pada batuk

- Gangguan pertumbuhan

- Stridor

- Gangguan menelan

- Pneumonia berulang

- Mengi

- Sesak

- Produksi sputum kronik

- Deformitas toraks

- Jari tabuh

- Auskultasi abnormal

- Hemoptisis

- Defisiensi imun

Tabel 2. Etiologi batuk kronik menurut kelompok umur ${ }^{7}$

\begin{tabular}{|c|c|c|}
\hline Bayi & Balita & Anak besar \& remaja \\
\hline $\begin{array}{l}\text { Kelainan kongenital } \\
\text { - } \quad \text { Trakeomalasia } \\
\text { - } \quad \text { Bronkomalasia } \\
\text { - } \quad \text { Vascular ring } \\
\text { - } \quad \text { Fistula trakeo-esofagus } \\
\text { Infeksi } \\
\text { - } \quad \text { Pertusis } \\
\text { - Klamidia } \\
\text { - } \quad \text { RSV } \\
\text { - } \quad \text { Adenovirus } \\
\text { - Parainfluenza } \\
\text { Asma } \\
\text { Aspirasi kronik } \\
\text { - Gangguan menelan (lambat } \\
\quad \text { kembang, palsi serebral, } \\
\text { - } \quad \text { Refluks gastroesofagus } \\
\text { Lain-lain } \\
\text { - Merokok pasif } \\
\text { - Polusi lingkungan }\end{array}$ & $\begin{array}{l}\text { - Aspirasi benda asing } \\
\text { - Post infectious cough } \\
\text { - Asma } \\
\text { - Tuberkulosis } \\
\text { - Pertusis } \\
\text { - Otitis media kronik } \\
\text { - Refluks gastroesofagus } \\
\text { - Bronkiektasis: post infectious, } \\
\text { primary ciliary dyskinesia, } \\
\text { sindrom imunodefisiensi }\end{array}$ & $\begin{array}{ll}\text { - } & \text { Asma } \\
\text { - } & \text { Perokok (pasif/aktif) } \\
\text { - } & \text { Infeksinal (viral, bakterial, } \\
\text { - } & \text { Tubipikal, fungal) } \\
\text { - Otitis media kronik } \\
\text { - } \text { Bronkiektasis } \\
\text { - } \text { Psikogen } \\
\text { - Tumor } \\
\text { - } \text { Primary ciliary dyskinesia } \\
\text { - Sindrom imunodefisiensi }\end{array}$ \\
\hline
\end{tabular}


ditanyakan apakah batuk produktif atau kering, tunggal atau berturutan. Anak kecil tidak selalu bisa mengekspektorasikan dahak, biasanya mereka akan menelan apa yang dibatukkan atau kemudian memuntahkannya. ${ }^{7}$ Pertanyaan lain meliputi kapan batuk, apakah lebih sering terjadi dari pada biasa, apakah timbul pada malam hari, apakah mengganggu tidur, bagaimana bunyi batuk, apakah ada gejala penyerta, (demam, mengi, sesak), apakah sebelumnya pernah terjadi dengan pola yang sama? Hal lain yang perlu digali, apakah ada hal yang memperberat atau meringankan gejala. Secara khusus tanyakan pencetus yang lazim pada asma (aktivitas, tertawa, menangis, pajanan udara dingin, perubahan cuaca, debu, asap rokok, asap dapur, asap obat nyamuk, atau rontokan bulu binatang) dan apakah memperburuk gejala. ${ }^{7}$ Pertanyaan lain meliputi terapi apa yang pernah didapat, dan bagaimana hasilnya. Respons yang kurang terhadap bronkodilator pada asma seringkali dijumpai akibat dosis tidak adekuat dan waktu pemberian yang tidak tepat. Perlu digali pula adanya gejala lain yang menyertai batuk, apakah anak mengalami gangguan tumbuh kembang, apakah batuk mengganggu aktivitas sehari-hari dan menurunkan kualitas hidup anak. ${ }^{7}$

Anamnesis yang baik akan memberikan petunjuk berharga. Sebagai contoh, batuk produktif yang timbul setelah posisi berbaring mengarah ke kemungkinan PND atau refluks GE. Batuk paroksismal mungkin disebabkan oleh pertusis, klamidia, atau benda asing yang terhirup. Batuk berulang disertai mengi disebabkan oleh obstruksi trakeobronkial (misalnya karena asma, benda asing, tumor mediastinum). Batuk yang berkaitan dengan makan atau proses menelan menunjukkan aspirasi ke dalam trakeobronkus. Ini dapat disebabkan oleh refluks GE, gangguan menelan karena kelainan saraf, atau mungkin karena fistel trakeo-esofagus. Batuk disertai suara serak atau hilang mungkin karena benda asing di laring, papiloma laring, atau croup. Batuk darah dapat disebabkan oleh batuk hebat yang ditimbulkan oleh sebab apapun. Namun kemungkinan tuberkulosis, bronkiektasis, atau benda asing perlu dipertimbangkan. ${ }^{7}$ (Tabel 4)

\section{Pemeriksaan fisis}

Unsur penting dalam pemeriksaan fisis dapat dilihat dalam Tabel 4. Pada batuk kronik semata tanpa kelainan paru yang serius, pemeriksaan fisis anak dapat normal, tanpa kelainan yang khusus. Namun tetap perlu dicari berbagai kelainan fisis yang khas misalnya nyeri tekan paranasal, tanda cairan atau infeksi di telinga tengah. Tanda-tanda alergi bila ditemukan akan membantu penegakan diagnosis. Pada anak asma, pemeriksaan fisis mungkin menunjukkan peningkatan diameter anteroposterior toraks, retraksi, mengi, atau ronki.?

Temuan klinis lain seperti deviasi trakea menunjukkan paru kolaps ipsilateral, atau masa di kontralateral. Gambaran cobblestone di retrofaring, menunjukkan kemungkinan PND kronik. Telinga juga perlu diperiksa secara khusus atas kemungkinan adanya benda asing. Anak balita kadang memasukkan benda-benda kecil ke dalam lubang tubuh termasuk telinga. Seperti kita ketahui, pada sebagian orang di liang telinga tengah dijumpai ujung saraf aurikular (Arnold nerve) yang akan meneruskan rangsangan mekanik ke pusat batuk. Benda asing di telinga atau kadang serumen yang mengeras dapat menimbulkan gejala batuk kronik. ${ }^{7}$

Tabel 4. Anamnesis dan pemeriksaan fisis anak dengan batuk kronik ${ }^{7}$

\begin{tabular}{ll}
\hline Anamnesis & Pemeriksaan fisis \\
\hline - Umur awitan & - Tumbuh kembang \\
- Karakteristik batuk & - Status nutrisi \\
- Saat timbul batuk & - Jari tabuh (clubbing fingers) \\
- Gejala penyerta & - Tanda-tanda sinusitis \\
- Faktor pencetus & - Tanda-tanda alergi: geographic tongue, allergic \\
- Pengaruh lingkungan dan cuaca & shiners, Dennie crease \\
- Respons terhadap terapi sebelumnya & - Toraks: asimetri, kelainan bentuk (pectus \\
& excavatum, pectus carinatum), hipersonor, \\
& redup, ronki, mengi. \\
\hline
\end{tabular}


Sari Pediatri, Vol. 6, No. 2, September 2004

\section{Pemeriksaan penunjang}

Foto toraks perlu dibuat pada semua pasien batuk kronik, bila ada foto lama ikut dievaluasi. ${ }^{7}$ Foto toraks perlu dibuat pada hampir semua anak dengan batuk kronik untuk menyingkirkan kelainan respiratorik bawah dan patologi kardiovaskular. ${ }^{5}$ Uji fungsi paru dilakukan pada semua anak yang sudah mampu laksana (di atas lima tahun), sebelum dan setelah pemakaian bronkodilator. ${ }^{7}$ Peran uji fungsi paru pada anak terbatas karena banyak anak tidak mampu melakukannya, dan hasil positif tidak selalu menegakkan diagnosis atau memprakirakan respons positif terhadap terapi tertentu. ${ }^{5}$ Prevalens tuberkulosis di Indonesia termasuk yang tertinggi di dunia; oleh karena itu skrining tuberkulosis dengan uji tuberkulin perlu dilakukan pada anak-anak, terlebih dengan gejala batuk kronik.

Bila dicurigai adanya refluks gastro-esofagus, perlu dilakukan pemeriksaan monitoring $24 \mathrm{jam}$ pH esofagus, bila perlu dilakukan pemeriksaan endoskopi. ${ }^{12}$ Foto sinus paranasalis terindikasi pada pasien dengan IRA disertai sekret purulen, batuk yang bertambah pada posisi telentang, nyeri daerah frontal, dan nyeri tekan / ketok di atas sinus. CT scan sinus lebih dianjurkan terutama untuk anak kecil yang sinusnya belum berkembang sepenuhnya. Foto dengan kontras barium diperlukan pada kasus batuk yang berhubungan dengan pemberian makanan, batuk yang disertai stridor atau mengi yang terlokalisir di saluran respiratorik besar. Pemeriksaan imunologis (IgG, IgE, IgM, IgA) perlu dilakukan pada kasus batuk yang berhubungan dengan otitis berulang, bronkiektasis, atau batuk produktif yang tidak responsif dengan antibiotik. ${ }^{7}$

\section{Tata Laksana}

Menghadapi anak dengan batuk kronik seringkali membuat frustasi orang tua atau anak tersebut bila sudah cukup besar. Biasanya pasien sudah dibawa berkeliling konsultasi kepada banyak dokter, umum maupun spesialis. Bagi dokterpun tidak jarang timbul rasa penasaran bahkan kesal jika batuk kronik tidak kunjung membaik.

Keberhasilan tata laksana batuk kronik tergantung pada keberhasilan diagnosis penyebabnya. Oleh karena itu usaha paling keras dalam tata laksana batuk kronik adalah dalam penentuan diagnosis secara sistematik. ${ }^{12,4}$ Tata laksana untuk batuk kronik harus ditujukan kepada penyebabnya. ${ }^{12,7}$ Pada pasien dewasa penyebab batuk kronik dapat ditentukan pada hampir seluruh kasus, dan mengarahkan keberhasilan terapi pada sebagian besar di antaranya. Melihat keberhasilan yang tinggi ini terapi batuk non-spesifik perannya sangat terbatas pada tata laksana batuk kronik. ${ }^{5}$ Hasil yang sama dapat diharapkan dalam tata laksana batuk kronik pada anak. ${ }^{7}$

Sebelum melakukan tindakan lebih lanjut, langkah pertama yang perlu dilakukan dalam tata laksana batuk kronik adalah penghentian pajanan dengan asap rokok (merokok pasif). Tata laksana batuk kronik pada anak yang termasuk kelompok I termasuk penjelasan untuk menenangkan pasien dan orang tua, karena batuk biasanya memerlukan waktu 4-8 minggu untuk sembuh. ${ }^{4}$ Untuk batuk kronik pada pasien anak dengan kelainan respiratorik yang nyata, hasilnya mungkin tidak sebaik dibandingkan kelompok pertama. Batuk yang berhubungan dengan penyakit paru kronik tidak boleh ditekan tetapi diberdayakan. Pasien dan orang tuanya perlu diberi edukasi bahwa batuk merupakan mekanisme alami yang berguna dan melindungi, dan bukannya harus dihentikan dengan cara apapun. ${ }^{7}$

Farmakoterapi untuk batuk dibagi dalam dua jenis, yaitu (a) antitusif untuk mencegah, mengendalikan, dan menekan batuk, atau (b) protusif untuk membuat batuk lebih efektif. Terapi antitusif terindikasi bila batuk tidak mempunyai manfaat, misalnya batuk yang timbul akibat rangsangan di faring. ${ }^{5}$ Antitusif nonspesifik ditujukan kepada gejala bukan kepada penyebab atau mekanisme batuknya, oleh karena itu terapi antitusif perannya sangat terbatas. Obat ini terindikasi hanya bila terapi definitif dan spesifik tidak dapat diberikan, baik karena etiologinya tidak diketahui, batuk yang demikian hebat atau bila terapi definitif tidak akan berhasil, misalnya batuk karena kanker paru. ${ }^{12,5}$ Peran terapi antitusif terbatas karena besar kemungkinan identifikasi etiologi batuk, dan terapi spesifik bisa berhasil. ${ }^{5}$ Protusif terindikasi bila batuknya bermanfaat dan perlu diberdayakan, yaitu pada kelainan respiratorik yang menghasilkan banyak sekresi, misalnya bronkiektasis, bronkitis, pneumonia, atelektasis paru. Dari beberapa studi yang dievaluasi beberapa obat protusif yang dinyatakan efektif adalah salin hipertonik, erdostein, dan terbutalin. ${ }^{5}$

\section{Daftar Pustaka}

1. Chung KF. The clinical and pathophysiological chal- 
lenge of cough. Dalam: Chung KF, Widdicombe J, Boushey H, Penyunting. Cough. Massachusetts: Blackwell Publishing, 2003. h. 3-10.

2. Phelan PD. Cough. Dalam: Phelan PD, Olinsky A, Robertson CF. Penyunting Respiratory illness in children. Oxford: Blackwell S Publications 1994.

3. Chang $\mathrm{AB}$. Causes, assessement and measurement of cough in children. Dalam: Chung KF, Widdicombe J, Boushey H. Penyunting. Cough. Massachusetts: Blackwell Publishing, 2003. h. 57-73.

4. De Jongste, Shields MD. Chronic cough in children. Thorax 2003; 58: 998-1003.

5. Irwin RS, Boulet LP, 7tier MM. Managing cough as a defense mechanism and as a symptom. A consensus panel report of the American College of Chest Physicians. Chest 1998; 114:133S-181S.

6. Munyard P, Bush A. How much coughing is normal?
Arch Dis Child 1996; 74:531-4.

7. Cloutier MM. Cough. Dalam: Loughlin GM, Eigen H. Penyuntings. Respiratory disease in children. Baltimore. Williams \& Wilkins 1994.

8. Irwin RS, Madison JM. The diagnosis and treatment of cough. N Engl J Med 2000; 343: 1715-21.

9. Santosa G. Pendekatan klinik batuk kronik dan atau berulang pada anak. Pidato pengukuhan Guru Besar. Universitas Airlangga 1991

10. Chang AB. Cough, cough receptors, and asthma in children. Pediatr Pulmonol 1999; 28: 59-70.

11. Campanella SG, Asher MI. Current controversies: sinus disease and the lower airways. Pediatr Pulmonol 2001; 31: 165-72.

12. Chung KF. Management of cough. Dalam: Chung KF, Widdicombe J, Boushey H. Penyunting. Cough. Massachusetts: Blackwell Publishing, 2003. h. 283-97. 